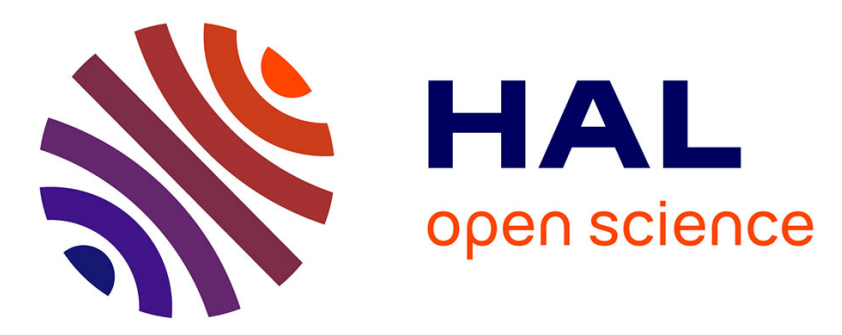

\title{
Characterization of the performances of an innovative heat-exchanger/reactor
}

Félicie Theron, Zoé Anxionnaz-Minvielle, Michel Cabassud, Christophe Gourdon, Patrice Tochon

\section{To cite this version:}

Félicie Theron, Zoé Anxionnaz-Minvielle, Michel Cabassud, Christophe Gourdon, Patrice Tochon. Characterization of the performances of an innovative heat-exchanger/reactor. Chemical Engineering and Processing: Process Intensification, 2014, vol. 82, pp. 30-41. 10.1016/j.cep.2014.04.005 . hal01346088

\section{HAL Id: hal-01346088 \\ https://hal.science/hal-01346088}

Submitted on 18 Jul 2016

HAL is a multi-disciplinary open access archive for the deposit and dissemination of scientific research documents, whether they are published or not. The documents may come from teaching and research institutions in France or abroad, or from public or private research centers.
L'archive ouverte pluridisciplinaire $\mathbf{H A L}$, est destinée au dépôt et à la diffusion de documents scientifiques de niveau recherche, publiés ou non, émanant des établissements d'enseignement et de recherche français ou étrangers, des laboratoires publics ou privés. 


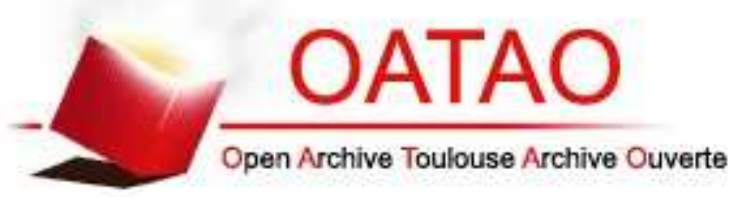

\section{Open Archive TOULOUSE Archive Ouverte (OATAO)}

OATAO is an open access repository that collects the work of Toulouse researchers and makes it freely available over the web where possible.

This is an author-deposited version published in : http://oatao.univ-toulouse.fr/ Eprints ID : 15982

To link to this article : DOI : 10.1016/j.cep.2014.04.005

URL : http://dx.doi.org/10.1016/j.cep.2014.04.005

To cite this version : Théron, Felicie and Anxionnaz-Minvielle, Zoé and Cabassud, Michel and Gourdon, Christophe and Tochon, Patrice Characterization of the performances of an innovative heatexchanger/reactor. (2014) Chemical Engineering and Processing: Process Intensification, vol. 82. pp. 30-41. ISSN 0255-2701

Any correspondence concerning this service should be sent to the repository administrator: staff-oatao@ listes-diff.inp-toulouse.fr 


\title{
Characterization of the performances of an innovative heat-exchanger/reactor
}

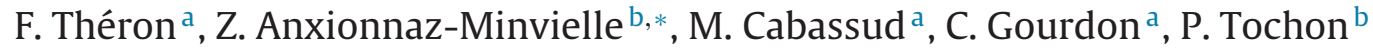 \\ a University of Toulouse, Laboratoire de Génie Chimique, UMR 5503, CNRS/INPT/UPS, 31432 Toulouse, France \\ b CEA, LITEN, LETH, 17 rue des Martyrs, 38054 Grenoble, France
}

Keywords:

Heat exchanger/reactor

Corrugated flow

Exothermal reaction

Continuous mode

Heat and mass transfer intensification

\begin{abstract}
A B S T R A C T
The use of heat exchanger/reactors (HEX/reactors) is a promising way to overcome the barrier of poor heat transfer in batch reactors. However to reach residence time long enough to complete the chemistry, low Reynolds number has to be combined with both a plug flow behaviour and the intensification of heat and mass transfers. This work concerns the experimental approach used to characterize an innovative HEX/reactor. The pilot is made of three process plates sandwiched between five utility plates. The process stream flows in a $2 \mathrm{~mm}$ corrugated channel. Pressure drop and residence time distribution characterizations aim at studying the flow hydrodynamics. Identified Darcy correlations point out the transition between laminar and turbulent flow around a Reynolds number equal to 200. Moreover the flow behaves like a quasi-plug flow ( $P e>185)$. The heat transfer and mixing time have also been investigated. The ratio between the reaction kinetics and the mixing time is over 100 and the intensification factor ranges from 5000 to $8000 \mathrm{~kW} \mathrm{~m}^{-3} \mathrm{~K}^{-1}$. As a consequence, no limitations were identified which allows the implementation of an exothermic reaction. It has been successfully performed under severe temperature and concentration conditions, batchwise unreachable. Thus, it highlights the interest of using this continuous HEX/reactor.
\end{abstract}

\section{Introduction}

Among the different ways of process intensification [1], the batch-to-continuous transposition is one of the most classical, provided that the reactor has to behave as plug flow reactor. The main issues in such apparatuses are to intensify heat and mass transfers while operating at low-Reynolds flows usually characteristic of laminar flows. Indeed low fluid velocities, i.e. high residence times, are required to complete the chemistry although high heat and mass transfer coefficients are usually expected in turbulent flows. One solution to remove this barrier is to work with heat-exchanger/reactors [2-4]. These apparatuses combine a heat-exchanger and a reactor in the same unit. This allows an accurate control of the operating temperature which is one of the main barriers concerning the implementation of exo- or endo-thermal reactions in classical batch reactors. Moreover the corrugation of the reaction channel leads to the heat and mass transfers intensification while maintaining low Reynolds numbers [5-9]. Thus, by using heat exchanger/reactors many benefits are expected such as

\footnotetext{
* Corresponding author. Tel.: +33 0438783567; fax: +33 0438785161

E-mail address: zoe.minvielle@cea.fr (Z. Anxionnaz-Minvielle).
}

waste reduction, energy and raw materials saving, yield and selectivity increase, and cost reduction.

The aim of this paper is to investigate the performances of the continuous heat exchanger/reactor developed in the frame of the RAPIC R\&D project supported by the French Agency ANR $[7,10]$. The originality of this project which started in December 2007 and lasted 42 months was to develop an innovative low-cost heat-exchanger/reactor (HEX reactor) for the $10 \mathrm{~kg} \mathrm{~h}^{-1}$ nominal flowrate. The development strategy to reach this goal was to take into consideration the implementation constraints of an industrial exothermal reaction while being as close as possible to mature technologies of heat-exchanger. A complementary consortium was thus setup comprising one end-user (Rhodia Chemicals), one heatexchanger manufacturer (Fives Cryo), two French laboratories active in basic research on process engineering (LGC) and thermohydraulic engineering (LTN), and the Atomic and Alternative Energy Commission (CEA/LITEN) which handles the project coordination, the component design, and the reaction plates manufacture.

The first part of this paper deals with the presentation of the heat exchanger/reactor and the experimental set-up used to characterize it. Its hydrodynamic performances are then evaluated from pressure drop, residence time distribution and mixing times measurements. The object of the third part is the study of the reactor 


\begin{tabular}{|c|c|}
\hline \multicolumn{2}{|c|}{ Nomenclature } \\
\hline$A$ & heat exchange area $\left(\mathrm{m}^{2}\right)$ \\
\hline$C_{p}$ & heat capacity $\left(\mathrm{J} \mathrm{kg}^{-1} \mathrm{~K}^{-1}\right)$ \\
\hline$d_{\text {bends }}$ & distance between two successive bends ( $\mathrm{m}$ ) \\
\hline$d_{h}$ & hydraulic diameter $(\mathrm{m})$ \\
\hline De & Dean number \\
\hline$D_{a x}$ & axial dispersion coefficient $\left(\mathrm{m}^{2} \mathrm{~s}^{-1}\right)$ \\
\hline$D_{h}$ & hydraulic diameter (m) \\
\hline$E_{a}$ & activation energy $\left(\mathrm{J} \mathrm{mol}^{-1}\right)$ \\
\hline \multicolumn{2}{|c|}{$f_{\text {corrugation }}$ corrugation frequency $\left(\mathrm{s}^{-1}\right)$} \\
\hline$F_{p}$ & process volume flowrate $\left(\mathrm{Lh}^{-1}\right)$ \\
\hline & reaction rate constant $\left(\mathrm{L} \mathrm{mol}^{-1} \mathrm{~s}^{-1}\right)$ \\
\hline$L$ & process channel length (m) \\
\hline$L_{\text {total }}$ & total process channel length $(\mathrm{m})$ \\
\hline \multirow{2}{*}{$\begin{array}{l}m_{d w} \\
m_{w}^{0}\end{array}$} & mass of water equivalent to the Dewar vessel ( $\mathrm{kg}$ ) \\
\hline & $\begin{array}{l}\text { mass of water initially introduced in the Dewar ves- } \\
\text { sel (kg) }\end{array}$ \\
\hline$m_{p}$ & mass of sample poured in the Dewar vessel $(\mathrm{kg})$ \\
\hline$M_{p}$ & process mass flowrate $\left(\mathrm{kg} \mathrm{h}^{-1}\right)$ \\
\hline$M_{u}$ & utility mass flowrate $\left(\mathrm{kg} \mathrm{h}^{-1}\right)$ \\
\hline$N_{i}^{0}$ & $\begin{array}{l}\text { initial molar flowrate of the limiting reactant } \\
\left(\mathrm{mol} \mathrm{s}^{-1}\right)\end{array}$ \\
\hline$n_{i}^{0}$ & initial mole number of the limiting reactant (mol) \\
\hline$P e$ & Peclet number \\
\hline$Q_{\text {losses }}$ & heat losses \\
\hline$Q_{p}$ & heat exchanged by the process side $(\mathrm{W})$ \\
\hline \multirow{2}{*}{$\begin{array}{l}Q_{r, \text { total }} \\
R\end{array}$} & total heat reaction $(\mathrm{W})$ \\
\hline & gas constant $\left(\mathrm{J} \mathrm{mol}^{-1} \mathrm{~K}^{-1}\right)$ \\
\hline & channel curvature radius (m) \\
\hline $\operatorname{Re}$ & Reynolds number \\
\hline & process Reynolds number \\
\hline & utility Reynolds number \\
\hline$t$ & time $(s)$ \\
\hline & mixing time $(\mathrm{s})$ \\
\hline & residence time $(\mathrm{s})$ \\
\hline & $\begin{array}{l}\text { temperature in the Dewar vessel just before } \\
\text { introducing the reactive media }\left({ }^{\circ} \mathrm{C}\right)\end{array}$ \\
\hline$T_{e q, d w}$ & temperature at equilibrium in the Dewar vessel \\
\hline$T_{p, \text { in }}$ & process inlet temperature $\left({ }^{\circ} \mathrm{C}\right)$ \\
\hline & process outlet temperature $\left({ }^{\circ} \mathrm{C}\right)$ \\
\hline & utility inlet temperature $\left({ }^{\circ} \mathrm{C}\right)$ \\
\hline & utility outlet temperature $\left({ }^{\circ} \mathrm{C}\right)$ \\
\hline & process fluid velocity $\left(\mathrm{m} \mathrm{s}^{-1}\right)$ \\
\hline & global heat transfer coefficient $\left(\mathrm{W} \mathrm{m}^{-2} \mathrm{~K}^{-1}\right)$ \\
\hline V & process channel volume $\left(\mathrm{m}^{3}\right)$ \\
\hline \multicolumn{2}{|c|}{ Greek letters } \\
\hline$\Delta H_{r}$ & reaction heat $\left(\mathrm{J} \mathrm{mol}^{-1}\right)$ \\
\hline$\Delta P$ & pressure drop $(\mathrm{Pa})$ \\
\hline$\Delta T_{m l}$ & logarithmic mean temperature $\left({ }^{\circ} \mathrm{C}\right)$ \\
\hline$\Lambda$ & Darcy coefficient \\
\hline$\mu$ & viscosity (Pa s) \\
\hline$\rho$ & density $\left(\mathrm{kg} \mathrm{m}^{-3}\right)$ \\
\hline$\chi$ & conversion rate \\
\hline
\end{tabular}

thermal behaviour through the investigation of thermal profiles in the process channel during experiments consisting in cooling a hot process fluid by the utility side. Finally the heat removal ability of the heat exchanger/reactor is tested through the implementation of the highly exothermic reaction of sodium thiosulfate oxidation by hydrogen peroxide.
Table 1

Geometrical properties of the heat-exchanger/reactor.

\begin{tabular}{lcc}
\hline & Process stream & Utility stream \\
\hline Number of parallel channels & 1 & 16 \\
Number of plates for each stream & 3 & 4 \\
Individual channel width $(\mathrm{mm})$ & 2.0 & 2.0 \\
Individual channel depth $(\mathrm{mm})$ & 2.0 & 2.0 \\
Individual channel length, $L_{\text {total }}(\mathrm{mm})$ & 6700 & \\
Hydraulic diameter, $D_{h}(\mathrm{~mm})$ & 2.0 & 2.0 \\
Total fluid volume $\left(\mathrm{mm}^{3}\right)$ & 26.85 & 114.1 \\
Metal thickness between streams $(\mathrm{mm})$ & 2 & 2 \\
\hline
\end{tabular}

\section{The heat-exchanger reactor}

The process channel design has been optimized in the frame of the Rapic project in order to find a compromise between the reactor performances (heat transfer and mixing), the pumping power, the compactness and the manufacturing costs. Lab-scale mock-ups have been implemented to study the influence of the geometrical parameters (curvature radius, straight length between two bends, aspect ratio and bend angle) on the heat and mass transfer performances, the pressure drops and the residence time distribution. The whole approach is detailed in Ref. [9]. From both these works and the specifications of the End-User involved in the Rapic project, a corrugated geometry has been selected $[7,10]$. The pilot has been manufactured in accordance with the results of the geometry optimization. It consists in three reactive plates sandwiched between four utility plates. The reactive plates as well as the utility plates have been engraved by laser machining to obtain $2 \mathrm{~mm}$ square cross-section channels. Both reactive and utility channels designs are presented in Fig. 1(a) and (b), and their characteristics are detailed in Table 1.

The reactor material is $316 \mathrm{~L}$ stainless steel and the different plates have been assembled by hot isostatic pressing (HIP) $[7,10,11]$. After assembly the reactor has a $32 \mathrm{~cm}$ height, a $14 \mathrm{~cm}$ width, a $3.26 \mathrm{~cm}$ thickness, and a mass of $10.84 \mathrm{~kg}$, which makes it a very compact HEX reactor. The reactor has been dimensioned for a flowrate range from 1 to $15 \mathrm{~kg} \mathrm{~h}^{-1}$, which corresponds to residence times ranging from 7 to $40 \mathrm{~s}$.

\section{The experimental setup}

A schematic representation of the experimental set-up used to investigate the reactor performances is presented in Fig. 2. It involves two distinct fluid streams which enable to feed respectively the reactive channel or the utility circuit. The process line is equipped with two pumps and the utility circuit with a third one. Each pump is equipped with a mass flowmeter. Each process pump can be fed with its own reactant or by distilled water. The utility circuit is supplied by distilled water as coolant. The utility line temperature is fixed thanks to a thermally controlled bath located just upstream its entrance in the reactor.

The respective temperatures of the utility inlet and outlet are measured thanks to Pt100 sensors. For the reactive channel the inlet and outlet temperatures are measured thanks to K-type thermocouples. During experiments the different temperatures and flowrates are recorded.

Other specific sensors are added for the different steps of this study. They are presented and detailed in the related parts of this paper.

\section{Methods, results and discussion}

Before implementing a test reaction, the first part of these works aims at characterizing the hydrodynamic behaviour (pressure drop and residence time distribution) and the transfer mechanisms 


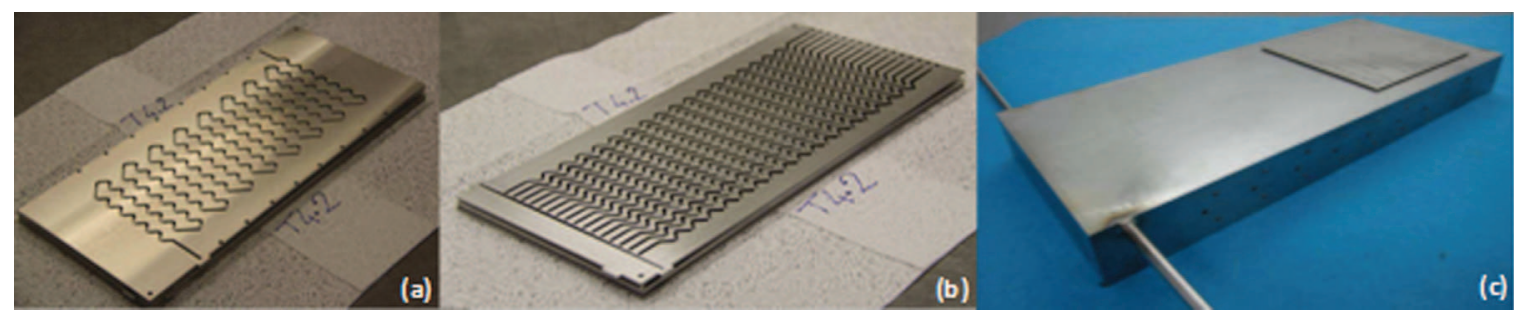

Fig. 1. (a) Reactive channel design; (b) utility channel design; (c) the heat exchanger/reactor after assembly.

(mixing and heat transfer) of the whole heat exchanger/reactor pilot.

\subsection{Pressure drop}

\subsubsection{Experimental set-up and procedure}

In order to carry out pressure drop measurements the reactive channel is equipped with a differential pressure sensor located between its inlet and outlet (cf. Fig. 2). Two Newtonian fluids are used to cover a wide Reynolds range: distilled water and a $67 \%$ weight aqueous solution of glycerol. The physico-chemical properties of both fluids are detailed in Table 2 as well as the flowrate ranges tested and the corresponding Reynolds numbers. The viscosity of the water-glycerol solution has been measured at $24^{\circ} \mathrm{C}$ with an AR 2000 rheometer (TA Instruments).

\subsubsection{Results and discussion}

The evolution of the pressure drop per length unit versus the flowrate for the reactive channel is presented in Fig. 3 for both fluids tested. The pressure drop measured with water ranges between 0.02 and 0.76 bars $\mathrm{m}^{-1}$, and for the water-glycerol solution it ranges between 0.14 and 2.38 bars $^{-1}$. These measurements enable to establish the relationships between the dimensionless Darcy $\Lambda$ and Reynolds Re numbers which are calculated as follows:

$\Lambda=\frac{2 \Delta P D_{h}}{\rho L u^{2}}$

$R e=\frac{\rho u D_{h}}{\mu}$

where $L$ is the total reactive channel length, and $u$ the process fluid velocity.

The evolution of the Darcy number as a function of the Reynolds number is presented in Fig. 4.

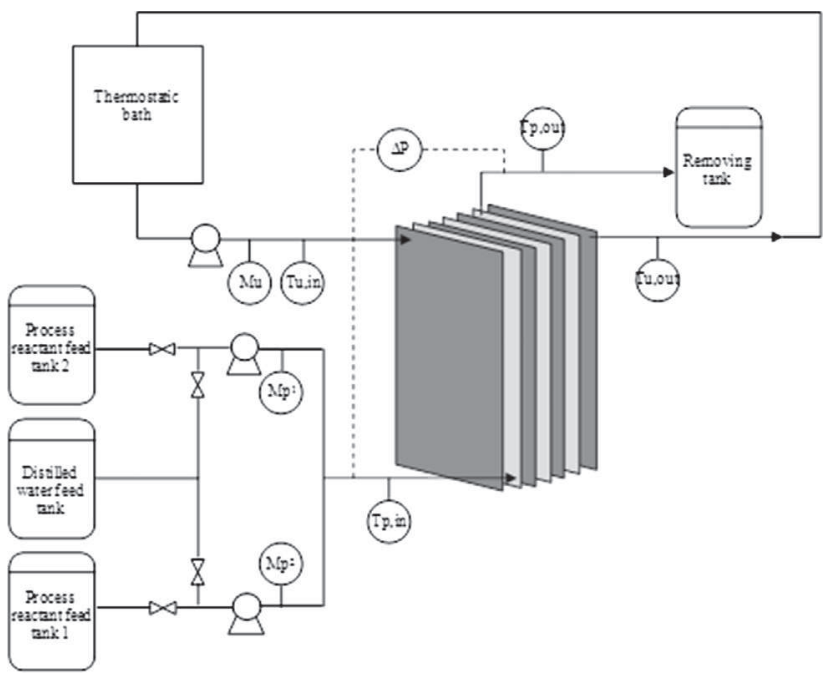

Fig. 2. Experimental set-up (grey: process plates; black: utility plates)

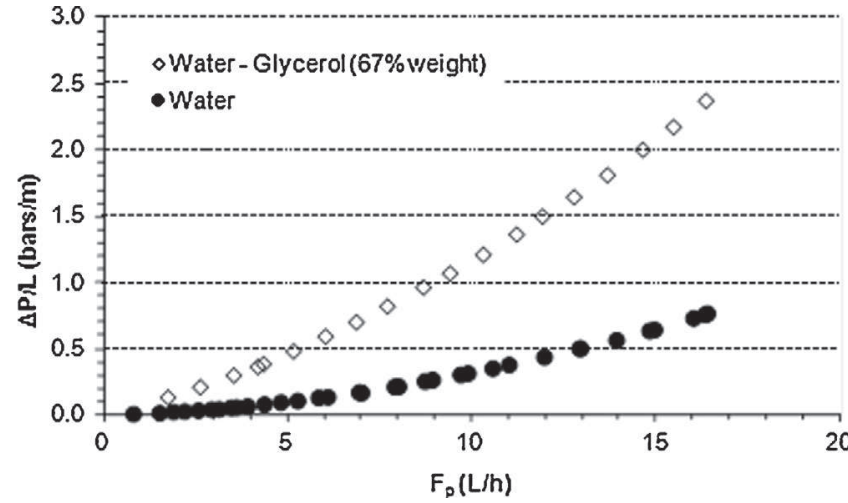

Fig. 3. Evolution of the pressure drop as a function of process flowrate for both fluids tested.

The general correlations between these numbers that can be found in the literature are of the following form:

$\Lambda=\frac{a}{R e^{b}}$

In the case of a square cross-section straight channel, the Darcy coefficient is written:

$\Lambda=0.9 \frac{64}{\operatorname{Re}}$

Reynolds numbers from 20 to 2250 have been explored without major discontinuity between the water experimental curve and the water/glycerol one. Only one point (water, $R e=100$ ) deviates from the correlation line. This discrepancy is attributed to the high uncertainty of the flow rate for this Reynolds number with water. Indeed, at $R e=100$, the water flow rate was very close to the lowest value of the flow meter range. Below a Reynolds number around 40, the pressure drop is not really affected by the channel corrugation and the Darcy coefficient is close to the one of a straight pipe. This result could be interesting for high viscous fluid applications for instance.

From the experimental results presented in Fig. 4 it is also possible to point out the transition between the laminar and

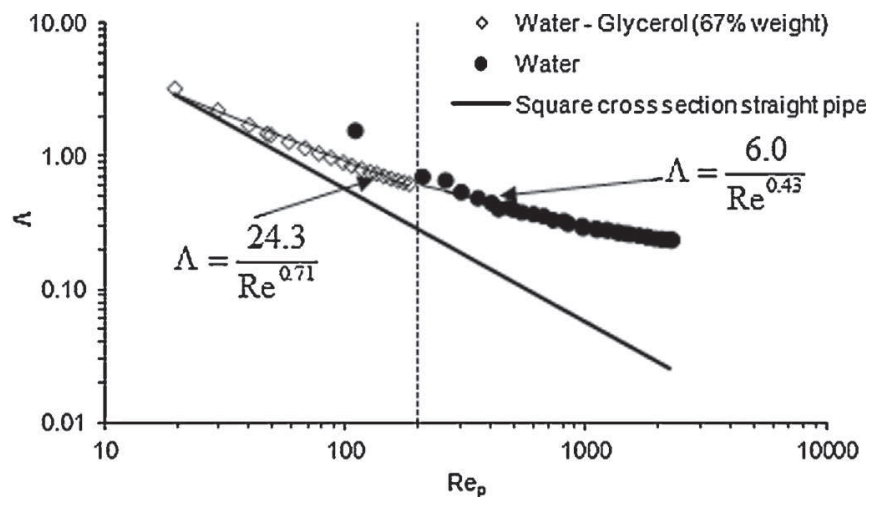

Fig. 4. Darcy number as a function of the Reynolds number. 
Table 2

Physico-chemical properties of fluid used for pressure drop measurements.

\begin{tabular}{lccc}
\hline Fluid & Density, $\rho\left(\mathrm{kg} \mathrm{m}^{-3}\right)$ & Viscosity, $\mu($ Pa s $)$ & Reynolds, Re \\
\hline Water & 993 & 0.0010 & $1.5-16.3$ \\
Water-glycerol (67\% weight) & 1162 & 0.0144 & $210-2250$ \\
\hline
\end{tabular}

the turbulent flow which operates at a Reynolds number around 200-300. The interest in lowering the transition point is linked to the compromise between residence time and intensification. Indeed the lower the Reynolds number, the higher the residence time (required for the chemistry). At the transition point, the flow is not laminar anymore which means that the pressure drop increases while the transfer mechanisms are enhanced thanks to the homogenization of the temperature, velocity and momentum gradients. As a consequence, if high residence times are required, this lowering of the transition point could be interesting. The relationships between the Darcy and the Reynolds numbers obtained from experimental results for both flow conditions are given in Fig. 4.

\subsection{Residence time distribution}

\subsubsection{Experimental set-up and procedure}

Residence time distribution experiments have been carried out to investigate the hydrodynamic characteristics of the heat exchanger/reactor. For this purpose a spectro-photometric method has been implemented. The coloured tracer used was potassium permanganate $\left(\mathrm{KMnO}_{4}\right)$ which absorbance wavelength is $525 \mathrm{~nm}$. The process fluid was water.

The experimental set-up was implemented with two measuring cells located respectively at the process stream inlet and outlet, and a "T" connector with a septum was added just upstream the inlet measurement cell to inject the tracer thanks to a syringe.

To perform RTD measurements the following procedure has been adopted:

- The water flowrate is fixed to the targeted value.

- When steady-state is reached the inlet and outlet absorbance signals recording is started and the tracer is injected trying to reproduce a signal as close as possible to a Dirac pulse.

- Recording is stopped when the signal returned to the baseline.

For this RTD study, six process flowrates ranging from 2.7 to $14.8 \mathrm{~L} \mathrm{~h}^{-1}$ have been tested, which correspond to Reynolds number ranging from 375 to 2056. Experiments have been performed at room temperature, and every experimental condition was repeated in order to get at least three reliable runs to evaluate the reproducibility of the measurement method.

\subsubsection{Results and discussion}

The RTD curves obtained for process flowrates of respectively $2.7 \mathrm{Lh}^{-1}$ and $14.8 \mathrm{Lh}^{-1}$ are presented in Figs. 5 and 6. These RTD curves are plotted as a function of relative times, that is to say the ratio between the time from the inlet peak to the theoretical residence time.

After about 1.3 times the theoretical residence time, the RTD curves do no longer exhibit tails. This means that the process channel of the heat-exchanger/reactor has no dead zones, recirculations or stagnant volumes. Moreover the RTD curve corresponding to the process flowrate of $2.7 \mathrm{~L} \mathrm{~h}^{-1}$ exhibits a longer tail than the one corresponding to the process flowrate of $14.8 \mathrm{Lh}^{-1}$. Thus increasing the flowrate enables to get closer to a plug flow behaviour.

From the deconvolution of the experimental RTD curves at the inlet and the outlet of the reactor and assuming an axial

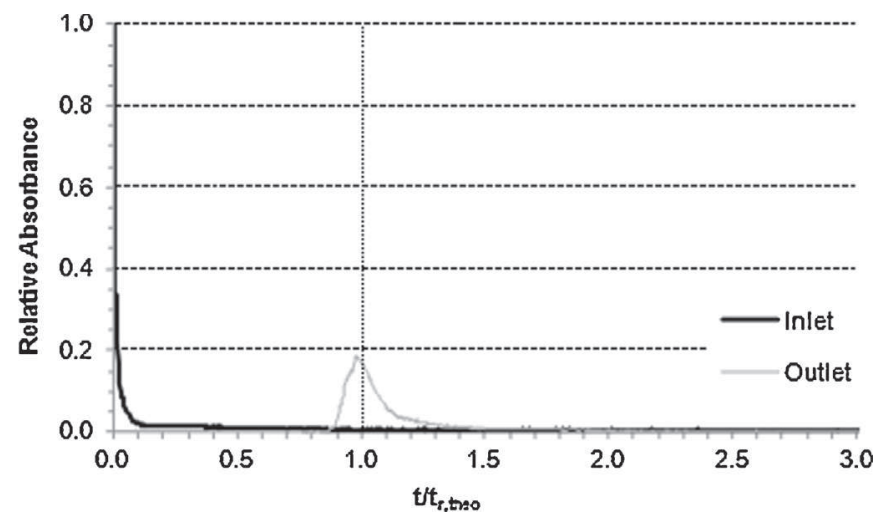

Fig. 5. RTD curve for $F_{p}=2.7 \mathrm{Lh}^{-1} ; R e_{p}=375$.

dispersion model with open boundaries, the Peclet number Pe has been assessed. It is defined as:

$P e=\frac{u \cdot L}{D_{a x}}$

where $u$ is the process fluid velocity, $L$ is the process channel length and $D_{a x}$ is the axial dispersion coefficient.

At the lowest flowrate, i.e. $2.7 \mathrm{Lh}^{-1}$, the Peclet number is already equal to 185 which confirms that the flow in the heatexchanger/reactor behaves like a quasi-plug flow.

\subsection{Mixing times}

A way to assess mixing times is to perform the reaction of discolouration of an iodine solution with sodium thiosulfate according to the following scheme [12]:

$\mathrm{I}_{2}$ (brown) $+2 \mathrm{Na}_{2} \mathrm{~S}_{2} \mathrm{O}_{3}$ (colourless) $\rightarrow 2 \mathrm{NaI}$ (colourless)

$+\mathrm{Na}_{2} \mathrm{~S}_{4} \mathrm{O}_{6}$ (colourless)

This homogeneous reaction is instantaneous and mixing limited. As a consequence, at steady state, the mixing time can be easily determined by measuring the required length to complete the discolouration of iodine.

However the length assessment requires tests to be performed in a transparent material in order to visualize the discolouration.

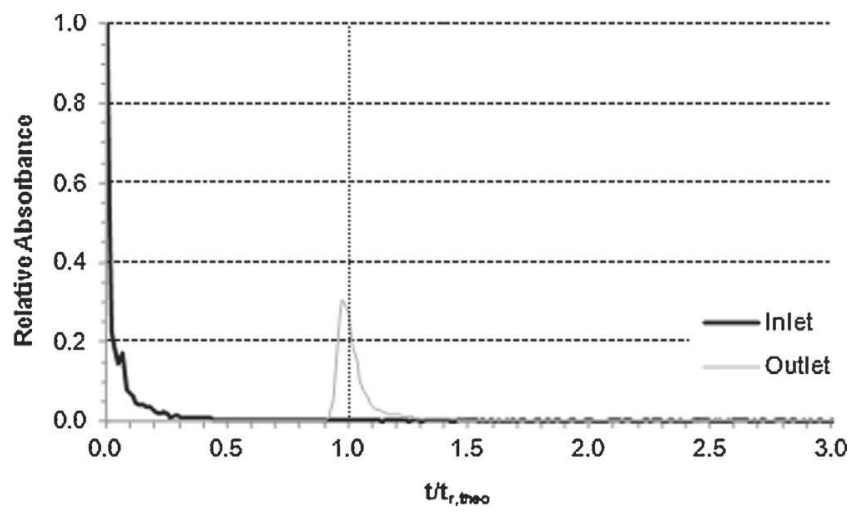

Fig. 6. RTD curve for $F_{p}=14.8 \mathrm{Lh}^{-1} ; R e_{p}=2056$. 


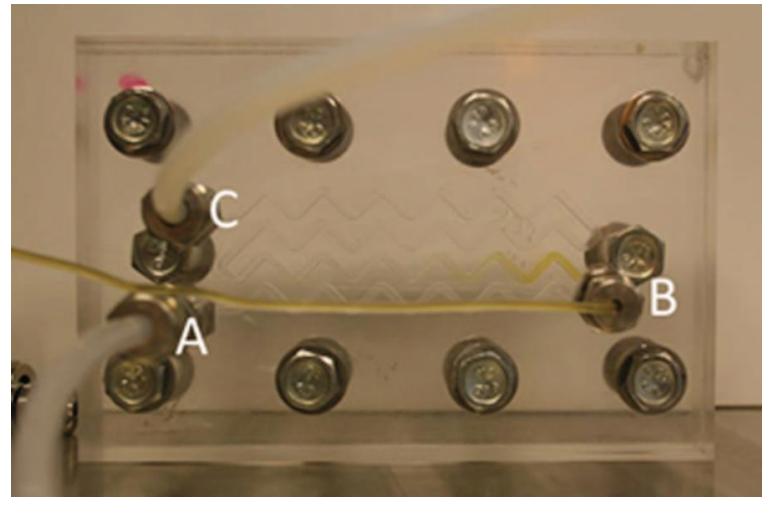

Fig. 7. Picture of the PMMA mock-up used for mixing tests.

As a consequence, the study of mixing times has been carried out in a PMMA mock-up. The channel geometry is strictly the same as the heat-exchanger/reactor one. Fig. 7 shows the PMMA mock-up used for the mixing tests.

Sodium thiosulfate and iodine are respectively fed in points $A$ and $\mathrm{B}$ while the products output is in point $\mathrm{C}$. A picture treatment makes easier the length assessment. Fig. 8 shows the mixing time profile versus the Reynolds number.

As expected the mixing time decreases when the Reynolds number increases. As a consequence for low Reynolds applications (involving viscous fluids for instance), mixing will have to be carefully considered to avoid mass transfer limitations. Above $R e=700$ mixing times are lower than $0.1 \mathrm{~s}$. This value has to be compared to the kinetics of the reaction implemented in this work in order to identify whether the reaction is limited by the mass transfer in the corrugated channel or not.

In classical mechanically stirred reactors the product of the agitation speed and the mixing time is constant in the turbulent flow regime [13]. By analogy we have considered a frequency, $f_{\text {corrugation, }}$, in the corrugated channel. It is defined as the ratio between the fluid velocity $u$, and the distance between two successive bends $d_{\text {bends }}(18.6 \mathrm{~mm})$ :

$f_{\text {corrugation }}=\frac{u}{d_{\text {bends }}}$

and this frequency has been multiplied by the measured mixing times $t_{m}$. Fig. 9 shows this parameter profile versus the Reynolds number.

This graph shows that the product $t_{m} \cdot f_{\text {corrugation }}$ seems constant above Reynolds $=300$. This means that from $R e=300$, the flow regime is similar to a turbulent one which is quite interesting for combining residence time while intensifying the mass transfer.

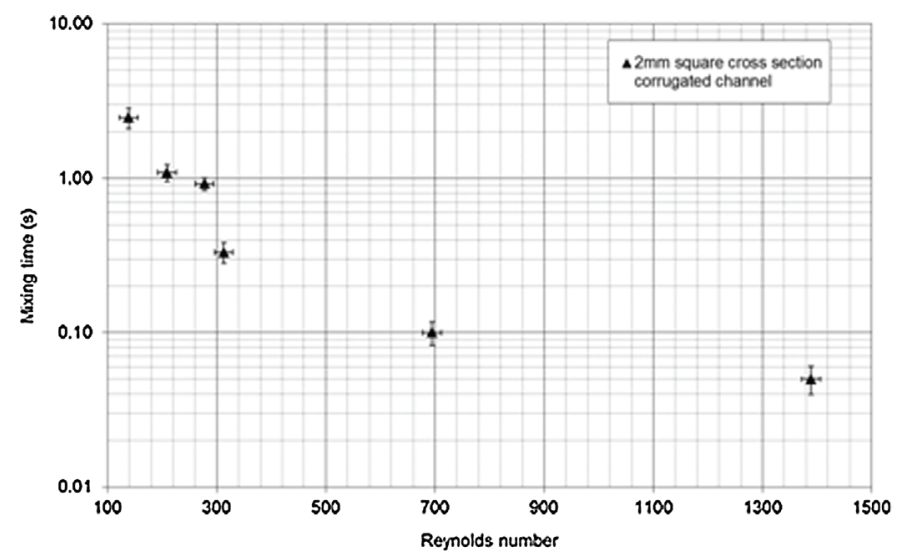

Fig. 8. Mixing time versus Reynolds number in the corrugated channel.

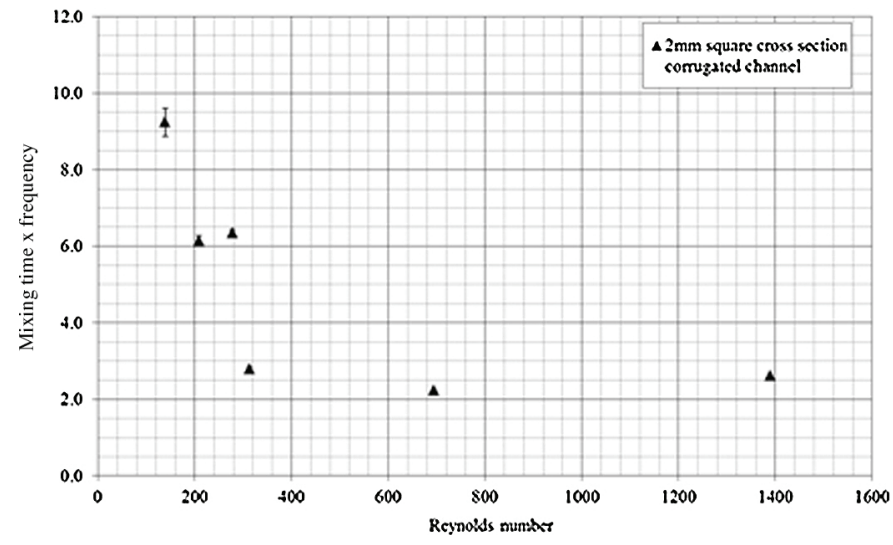

Fig. 9. Frequency of the corrugation $\times$ mixing time vs. Reynolds number.

Considering the experimental uncertainties, this result is consistent with the pressure drop results which shows a transition point around $R e=200$ (cf. Fig. 4).

An important dimensionless number to consider in corrugated geometries is the Dean number. It is defined as:

$D e=R e \cdot \sqrt{\frac{D_{h}}{R_{c}}}$

where $R e$ is the Reynolds number, $d_{h}$, the hydraulic diameter and $R_{c}$, the channel curvature radius.

Contrary to the flow in a straight channel, the streamlines in a corrugated channel are not parallel to the flow axis. The centrifugal force encountered in each bend and the imbalance between this force and the pressure gradient generate counter-rotating vortices in the channel cross-section. Dean [14] was the first to solve the flow solution in a curved duct.

An increase of the Dean number tends to move the axial velocity peak from the centre to the outward duct wall. Above a critical value of the Dean number, two additional vortices appear due to the flow instability. They are called the Dean vortices.

The critical Dean number ranges between 100 and 250 according to the employed Dean vortices detection method [15-18]. In the geometry of our heat-exchanger/reactor, the Dean number corresponding to a Reynolds number around 200, is equal to 230 . As a consequence the flow regime transition observed from both pressure drop and mixing results is consistent with the apparition of Dean vortices above the critical Dean number.

\subsection{Thermal characterization}

The aim of this part is to investigate the thermal performances of the heat exchanger/reactor and to estimate the heat transfer coefficients in order to compare it to other HEX reactors.

\subsubsection{Experimental set-up and procedure}

For this thermal characterization the process channel was instrumented with six K-type thermocouples. Five of them are located in the first process plate (cf. Fig. 10), and the sixth one just one row before the transition between the second and the third process plates. For this study the reactor is thermally insulated thanks to polystyrene. The configuration of process and utility plates is represented in Fig. 11. Each process plate exchanges heat with the two adjacent utility plates. Globally the streams flow co-currently on one side and counter-currently on the other side. However, locally the streams are close to a cross-flow configuration.

The method used to carry out this thermal characterization consists in cooling the process fluid that flows through a thermally controlled bath located upstream the process inlet. The process and 


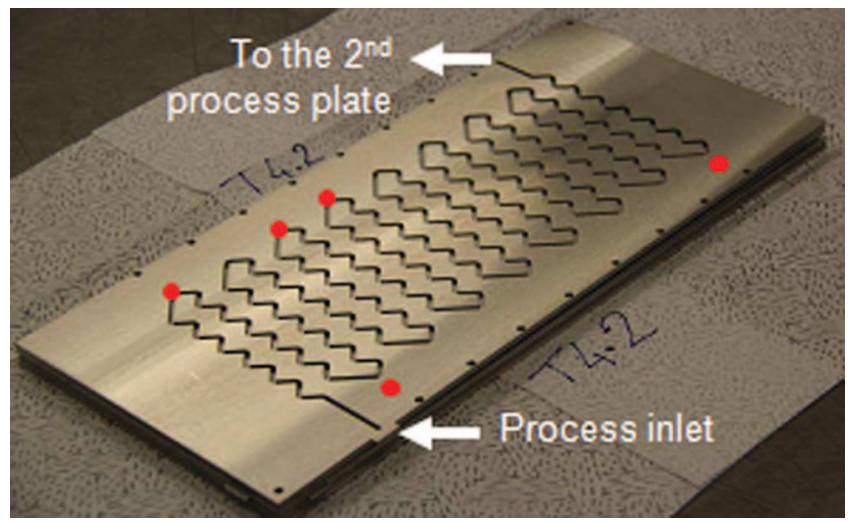

Fig. 10. Localization of the five thermocouples implemented in the first process plate.

utility fluid is water which temperature upstream the reactor inlet is about $75^{\circ} \mathrm{C}$ for the process stream, and about $15^{\circ} \mathrm{C}$ for the utility stream. The experimental procedure for each test is as follows:

- The process channel is fed with water at the targeted temperature and flowrate.

- When steady-state is reached the utility channel is also fed with water at the targeted temperature flowrate.

- The different temperatures are recorded until steady-state is reached.

Both process and utility flowrates influences are addressed in this study. The experimental conditions are detailed in Table 3.

\subsubsection{Thermal profiles}

Fig. 12 aims at evaluating the influence of the utility flowrate on the process stream temperature evolution along the process channel. All these experiments have been carried at a fixed process flowrate of $10 \mathrm{~kg} \mathrm{~h}^{-1}$. In this figure the temperature evolution is represented as a function of the ratio of the process channel position $\mathrm{L}$ at which the temperature is measured to the total process channel length $L_{\text {total }}$.

This graph shows that the temperature profile has the same evolution whatever the utility flowrate, and is almost constant from $111.3 \mathrm{~kg} \mathrm{~h}^{-1}$. This means that from this value the heat transfer process is not limited by the local heat transfer coefficient on the utility side. In the next section the utility flowrate is fixed to its highest value of about $152 \mathrm{~kg} \mathrm{~h}^{-1}$ for addressing the influence of the process flowrate.

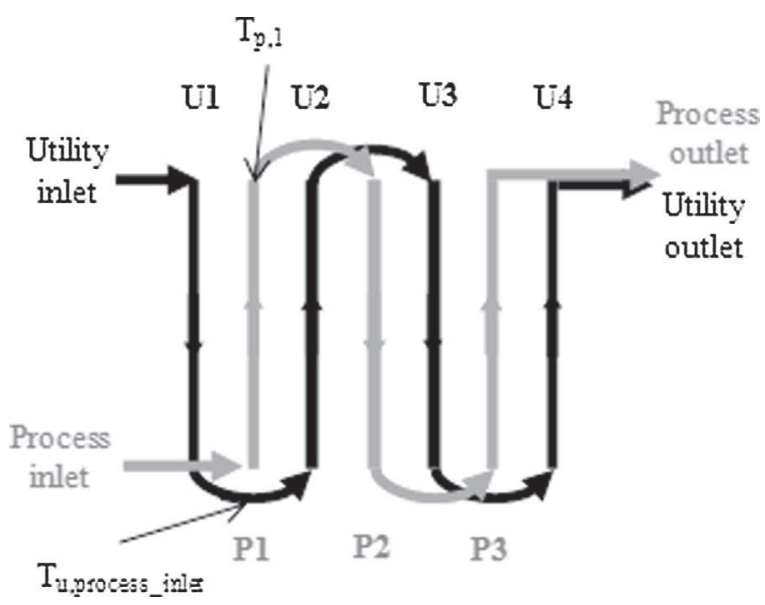

Fig. 11. Process and utility plates configuration for the thermal characterization.

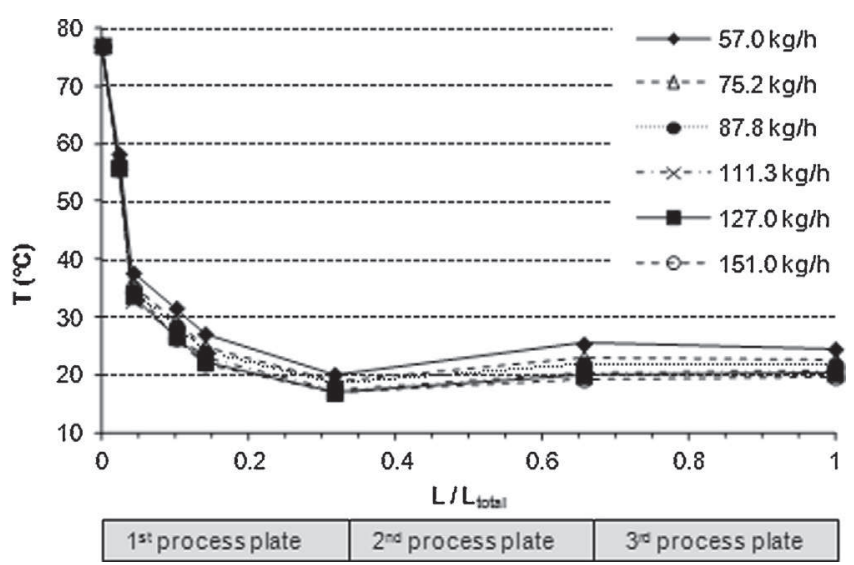

Fig. 12. Evolution of the process fluid temperature along the process channel for different utility flowrates, with $M_{p}=10 \mathrm{~kg} \mathrm{~h}^{-1}$ and $T_{p, i n}=77^{\circ} \mathrm{C}$.

Fig. 13 enables to evaluate the influence of the process flowrate on the process fluid temperature evolution along the process channel. This figure shows that whatever the process flowrate the temperature of the process stream decreases along the channel in the first process plate. Then the temperature slightly increases in the next two process plates. The minimum reached at the exit of the first process plate can be explained by the fact that at this point the process plate exchanges heat on one of its side with the utility inlet. Moreover it is considered that at this point the heat exchange between both sides is completed. In the following calculation of the intensification factor, the heat balance will thus be made from the temperature difference measured at the process channel inlet and at $L / L_{\text {total }}=0.32$, i.e. in the first process plate.

Fig. 14 represents the same experimental data as those represented in Fig. 13, but the temperature is plotted as a function of the residence time in the process channel. This representation points out that only $3 \mathrm{~s}$ are needed for the process fluid to reach its minimum temperature. In the perspective of implementing highly exothermal or endothermal reactions such results highlight the ability of the heat-exchanger/reactor to quickly remove heat.

\subsubsection{Discussion}

The thermal data allow the calculation of the intensification factor: $U \cdot A / V$, where $A$ is the exchange area, $V$ is the process channel volume and $U$ is the global heat transfer coefficient calculated as follows:

$U=\frac{Q_{p}}{A \cdot \Delta T_{m l}}$

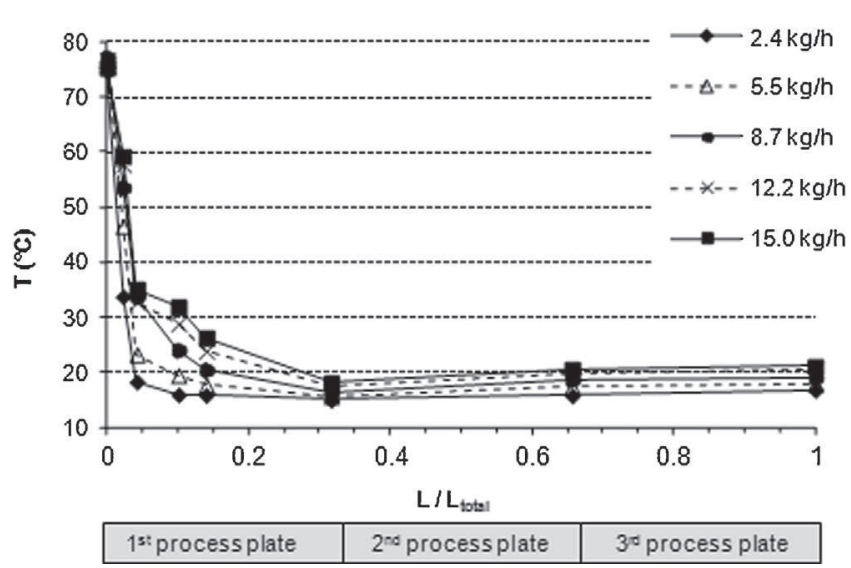

Fig. 13. Evolution of the process fluid temperature along the channel for different process flowrates, with $M_{u}=152 \mathrm{~kg} \mathrm{~h}^{-1}$ and $T_{u, i n}=15.6^{\circ} \mathrm{C}$. 
Table 3

Experimental conditions for the thermal characterization.

\begin{tabular}{|c|c|c|c|c|c|c|}
\hline \multicolumn{3}{|c|}{ Utility stream } & \multicolumn{4}{|c|}{ Process stream } \\
\hline$M_{u}\left(\mathrm{~kg} \mathrm{~h}^{-1}\right)$ & $R e_{u}$ & $T_{u, i n}\left({ }^{\circ} \mathrm{C}\right)$ & $M_{p}\left(\mathrm{~kg} \mathrm{~h}^{-1}\right)$ & $u\left(\mathrm{~m} \mathrm{~s}^{-1}\right)$ & $R e_{p}$ & $T_{p, \text { in }}\left({ }^{\circ} \mathrm{C}\right)$ \\
\hline & & & 2.4 & 0.2 & 554 & \\
\hline & & & 4.0 & 0.3 & 937 & \\
\hline & & & 5.5 & 0.4 & 1303 & \\
\hline & & & 6.9 & 0.5 & 1641 & \\
\hline \multirow[t]{5}{*}{$\approx 152$} & $\approx 1200$ & $\approx 15.6$ & 8.7 & 0.6 & 2082 & $\approx 76.0$ \\
\hline & & & 10.3 & 0.7 & 2469 & \\
\hline & & & 12.2 & 0.8 & 2935 & \\
\hline & & & 13.4 & 0.9 & 3140 & \\
\hline & & & 15.0 & 1.0 & 3583 & \\
\hline 57.0 & 499 & & & & & \\
\hline 62.2 & 544 & & & & & \\
\hline 75.2 & 641 & & & & & \\
\hline 87.8 & 742 & & & & & \\
\hline 101.3 & 846 & $\approx 15.6$ & $\approx 10.0$ & $\approx 0.7$ & $\approx 2400$ & $\approx 77.0$ \\
\hline 111.3 & 927 & & & & & \\
\hline 127.0 & 1044 & & & & & \\
\hline 138.8 & 1133 & & & & & \\
\hline 151.0 & 1239 & & & & & \\
\hline
\end{tabular}

where $Q_{p}$ is the heat exchanged by the process fluid:

$Q_{p}=M_{p} \cdot C_{p_{p}} \cdot\left(T_{p, i n}-T_{p, 1}\right)$

and $\Delta T_{m l}$ is the logarithmic mean temperature:

$\Delta T_{m l}=\frac{\left(T_{p, \text { in }}-T_{u, \text { process_inlet }}\right)-\left(T_{p, 1}-T_{u, \text { in }}\right)}{\ln \left(\left(T_{p, \text { in }}-T_{u, \text { process_inlet }}\right) /\left(T_{p, 1}-T_{u, \text { in }}\right)\right)}$

$T_{p, i n}$ as well as $T_{u, i n}$ are the inlet temperatures. As mentioned before $T_{p, 1}$ is the temperature measured at the first process plate exit. $T_{u, p r o c e s s i n l e t}$ is the utility side temperature physically corresponding to the process stream inlet, which is calculated by a heat balance considering that the heat exchanged by the process side is equal to the one exchanged by the utility side. The water heat capacity $C_{p p}$ is calculated at the mean process fluid temperature between the inlet and the outlet of the first plate.

Fig. 15 represents the intensification factor as a function of the process flowrate. The intensification factor increases from about 5000 to $8000 \mathrm{~kW} \mathrm{~m}^{-3} \mathrm{~K}^{-1}$ when the process flowrate ranges from 8.7 to $15.0 \mathrm{~kg} \mathrm{~h}^{-1}$.

The thermal performances of the heat-exchanger/reactor are compared to those of other HEX reactors reported in the literature in Table 4. According to this table the thermal performances of the heat-exchanger/reactor are rather interesting. Even if it does not allow residence times of the same order as other technologies,

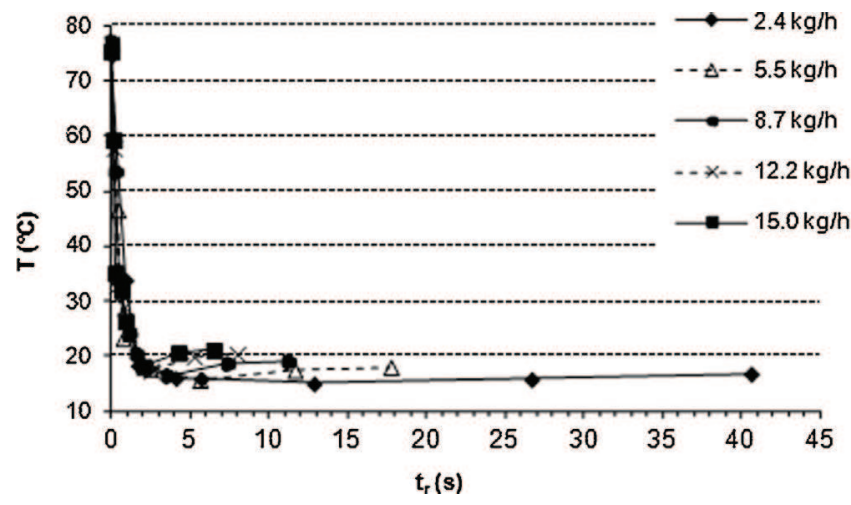

Fig. 14. Evolution of the process fluid temperature as a function of the residence time in the process channel for different process flowrates, with $M_{u}=152 \mathrm{~kg} \mathrm{~h}^{-1}$ and $T_{u, i n}=15.6^{\circ} \mathrm{C}$. the heat exchanger/reactor exhibits higher intensification factors than almost all of the other reactors. The residence time issue can be addressed by using several reactors in serial or by adding extraplates depending on the operating conditions required. The only apparatus that appears more interesting from the thermal performance standpoint is the heat exchanger reactor investigated by Despenes et al. [19] which is made of silicon carbide.

\subsection{Oxidation reaction}

The aim of the HEX reactors is to safely carry out reactions that involve important heat removal or supply issues under concentrated conditions. That is why a highly exothermic reaction has been selected in order to investigate the heat removal capacity of our heat-exchanger/reactor.

\subsubsection{The oxidation reaction}

The chosen reaction is the oxidation of sodium thiosulfate $\mathrm{Na}_{2} \mathrm{SO}_{3}$ by hydrogen peroxide $\mathrm{H}_{2} \mathrm{O}_{2}$ that occurs through the following equation:

$$
2 \mathrm{Na}_{2} \mathrm{~S}_{2} \mathrm{O}_{3}+4 \mathrm{H}_{2} \mathrm{O}_{2} \rightarrow \mathrm{Na}_{2} \mathrm{~S}_{3} \mathrm{O}_{6}+\mathrm{Na}_{2} \mathrm{SO}_{4}+4 \mathrm{H}_{2} \mathrm{O}
$$

Some authors carried out this reaction to characterize heat transfer during batch or semi-batch procedures [22,23], or to evaluate the performances of a tubular reactor [24] and of

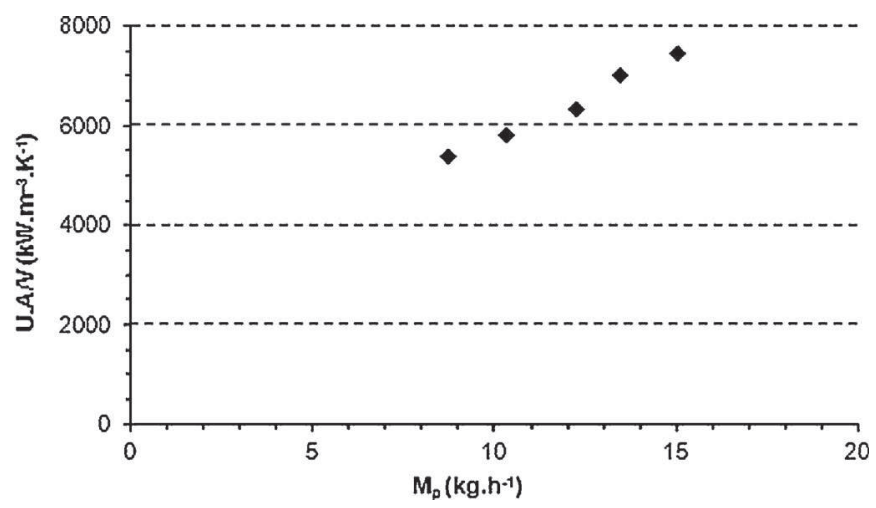

Fig. 15. Intensification factor as a function of the process flowrate, with $M_{u}=152 \mathrm{~kg} \mathrm{~h}^{-1}$ and $T_{u, i n}=15.6^{\circ} \mathrm{C}$. 
Table 4

Comparison of thermal performances of the RAPIC R\&D heat exchanger/reactor to other standard reactors.

\begin{tabular}{|c|c|c|c|c|}
\hline Reactor & Reference & Reactor description & Residence time & $\begin{array}{l}\text { Intensification factor } \\
U \cdot A / V\left(\mathrm{~kW} \mathrm{~m}^{-3} \mathrm{~K}^{-1}\right)\end{array}$ \\
\hline RAPIC R\&D heat exchanger/reactor & This work & & Few ten seconds & $5000-8000$ \\
\hline Silicon carbide based heat exchanger reactor & [19] & & Few minutes & 20,000 \\
\hline Stainless steel based heat exchanger reactor & [19] & & Few minutes & 5000 \\
\hline Chart ShimTec heat exchanger reactor & {$[20]$} & & Few minutes & 3000 \\
\hline Alfa-Laval heat exchanger reactor & [21] & & Few minutes & 1000 \\
\hline Batch reactor & & & Few hours & 1 \\
\hline
\end{tabular}

several HEX reactors $[20,21,25]$. This reaction occurs in homogeneous liquid phase, is irreversible, fast and its reaction heat is $\Delta H_{r}=-586.2 \mathrm{~kJ} \mathrm{~mol}^{-1}$. Moreover this reaction is temperature sensitive, i.e. the conversion rate depends on the operating temperature.

\subsubsection{Experimental set-up}

The oxidation reaction involves two aqueous solutions of sodium thiosulfate and hydrogen peroxide as reactants. The solubility limits of $\mathrm{Na}_{2} \mathrm{~S}_{2} \mathrm{O}_{3}$ and $\mathrm{H}_{2} \mathrm{O}_{2}$ in water are respectively 30 and $35 \%$ in mass [26]. To avoid too high temperatures inside the reactor in case of an adiabatic rise the two solutions are both prepared in order to reach $9 \%$ in mass.

As the process channel has only one inlet these solutions are mixed just upstream this inlet thanks to a "T" connection. The "premixing" of reactants before the reactor inlet does not lead to a reaction start because at this stage the process stream is not heated by the utility stream and as it was pointed out previously the reaction is temperature sensitive. The temperature of the premixing is the room temperature (cf. $T_{\text {premix }}$, Table 5). Thus the beginning of the reaction well occurs as the reactants premix enter the reactor (inlet temperatures ranges from 40 to $60^{\circ} \mathrm{C}$ ).

Sodium thiosulfate as well as hydrogen peroxide are rather unstable. Their concentrations are thus checked by titration before each experiment. The titration of the hydrogen peroxide solution is performed by manganimetry thanks to potassium dichromate [27], and the concentration of the sodium thiosulfate is carried out by iodometry [28].

Then the reactant solutions are poured in both process reactant feed tanks (cf. Fig. 2). As the reaction is not always completed at the reactor outlet, a high amount of ice is prepared to cool and dilute the process fluid in a tank to prevent from any thermal runaway.

The conversion rate at the reactor outlet is calculated thanks to two different methods detailed further. One of them is a calorimetric method that consists in calculating the adiabatic temperature rise of a sample of reactive media from the reactor outlet until the reaction end. For this purpose a known amount of the reactive media is poured into a Dewar vessel containing a known amount of distilled water. So before each experiment the water is poured in the Dewar vessel in which a thermocouple is located. 
Table 5

Operating conditions of oxidation reaction experiments.

\begin{tabular}{|c|c|c|c|c|c|c|c|}
\hline \multirow[t]{2}{*}{ No. exp } & \multicolumn{5}{|l|}{ Process side } & \multicolumn{2}{|l|}{ Utility side } \\
\hline & $F_{\mathrm{H}_{2} \mathrm{O}_{2}}\left(\mathrm{Lh}^{-1}\right)$ & $F_{\mathrm{Na}_{2} \mathrm{~S}_{2} \mathrm{O}_{3}}\left(\mathrm{Lh}^{-1}\right)$ & $R e_{p}$ & $t_{r}(\mathrm{~s})$ & $T_{\text {premix }}\left({ }^{\circ} \mathrm{C}\right)$ & $M_{u}\left(\mathrm{~kg} \mathrm{~h}^{-1}\right)$ & $T_{u, \text { in }}\left({ }^{\circ} \mathrm{C}\right)$ \\
\hline 1 & 4.7 & 9.3 & 2481 & 6.9 & 17.6 & 113.0 & 39.7 \\
\hline 2 & 1.7 & 3.3 & 879 & 19.3 & 19.3 & 113.5 & 39.7 \\
\hline 3 & 2.3 & 4.7 & 1266 & 13.8 & 20.0 & 113.0 & 39.7 \\
\hline 4 & 2.3 & 4.7 & 1378 & 13.8 & 20.7 & 112.0 & 49.6 \\
\hline 5 & 2.3 & 4.7 & 1498 & 13.8 & 21.1 & 112.5 & 59.4 \\
\hline
\end{tabular}

For these experiments the reactor is thermally insulated thanks to a polystyrene jacket.

\subsubsection{Experimental procedure}

Each experiment is carried out through the same procedure:

- The utility line is fed with water at the targeted temperature and flowrate. The process channel is also fed with water at room temperature at the total flowrate targeted for the reaction. This first step enables to calculate the heat losses.

- When the steady state is reached the process line is fed with the reactants.

- At steady state a fixed amount of reactive medium is poured into the Dewar vessel in order to calculate the conversion rate at the reactor outlet through the calorimetric method.

During each experiment the different temperatures (process and utility inlets and outlets and Dewar vessel) and flowrates (utility and both reactants solutions) are recorded. The total process flowrate is also measured by weighing at the reactor outlet.

The conditions of the five experiments performed are detailed in Table 5 . The concentrations of both sodium thiosulfate and hydrogen peroxide solutions are $9 \%$ weight.

\subsubsection{Calculation of the conversion rate at the reactor outlet}

The first method used to calculate the conversion rate $\chi$ in the reactor is based on a thermal balance between the process and utility inlets and outlets at steady state. The conversion is thus calculated as follows:

$\chi=\frac{Q_{\text {losses }}+M_{p} \cdot C_{p_{p}} \cdot\left(T_{p, \text { out }}-T_{p, \text { in }}\right)+M_{u} \cdot C_{p_{u}} \cdot\left(T_{u, \text { out }}-T_{u, \text { in }}\right)}{Q_{r, \text { total }}}$

where $M_{p}$ is the mass flowrate in the process channel.

$Q_{r, \text { total }}$ is the total heat reaction:

$Q_{r, \text { total }}=N_{i}^{0} \cdot \Delta H_{r}$

where $N_{i}^{0}$ is the initial molar flowrate of the limiting reactant $\left(\mathrm{Na}_{2} \mathrm{~S}_{2} \mathrm{O}_{3}\right)$.

The second method consists in a thermal balance on the sample of reactive media poured in the Dewar vessel from the reactor outlet. This thermal balance is based on measuring the adiabatic temperature rise in the vessel from the sampling to the reaction end, that is to say until the temperature equilibrium. The conversion rate at reactor outlet is thus calculated through the following equation:

$\chi=1-\frac{m_{p} \cdot C_{p_{p}}\left(T_{e q, d w}-T_{p, \text { out }}\right)+\left(m_{d w}+m_{w}^{0}\right) \cdot C_{p_{\text {water }}} \cdot\left(T_{e q, d w}-T_{d w}^{0}\right)}{n_{i}^{0} \cdot \Delta H_{r}}$

where $m_{p}, m_{w}^{0}$ and $m_{d w}$ are respectively the mass of the sample poured in the vessel, the mass of water initially introduced in the Dewar vessel and the mass of water equivalent to the mass of the Dewar vessel. $n_{i}^{0}$ is the initial mole number of the limiting reactant, $T_{e q, d w}$ is the temperature at equilibrium in the Dewar, and $T_{d w}^{0}$ is the temperature in the Dewar vessel just before introducing the reactive media.

\subsubsection{Results and discussion}

Fig. 16 shows the process and utility inlets and outlets temperature profiles during the experiment No. 1. During this experiment the reactor is fed with the reactant at $t=3340 \mathrm{~s}$. When the steady state is reached the process outlet temperature slightly exceeds the utility outlet temperature. The difference between these temperatures is of $4{ }^{\circ} \mathrm{C}$ which is not very important and highlights the heat removal ability of the reactor.

From the whole experiments, the conversion rate calculated according to both methods and the heat exchanged are summarized in Table 6. These results show that the thermal losses are rather low. The conversion rates calculated by both methods are in quite good agreement. The highest discrepancy between both values is of $13 \%$ for the second experiment. As expected the conversion rate increases when increasing either the residence time in the reactor or the temperature of the utility stream. $100 \%$ conversion rate is reached for experiments No. 4 and 5 carried out respectively with inlet utility temperatures of about 50 and $60^{\circ} \mathrm{C}$.

\subsubsection{Comparison to the literature kinetic data}

Different Arrhenius kinetic parameters can be found in the literature for this reaction. They are reported by Grau et al. [22] and summarized in Table 7. Among the different data the ones that best fit the experimental results are the values obtained by Grau et al. As a consequence Fig. 17 shows the conversion profile versus time obtained from both the Grau et al. kinetic law and the experimental data for a utility inlet temperature fixed to $39.7^{\circ} \mathrm{C}$. In this figure the kinetic constant has been calculated at $42.9^{\circ} \mathrm{C}$ which is the average of the 3 process outlet temperatures measured for the 3 experiments carried out at this inlet utility temperature.

At fixed utility inlet temperature the different flowrates experimentally tested enable to compare the conversion to the kinetic data reported in the literature at different stages of the reaction. Fig. 17 shows that for both conversion rates of 60 and $80 \%$ the kinetic model results fit well with the experimental data since the discrepancy is lower than $2 \%$ for the two extreme residence times. The highest discrepancy is obtained at the intermediate residence time which might be explained by an experimental deviation.

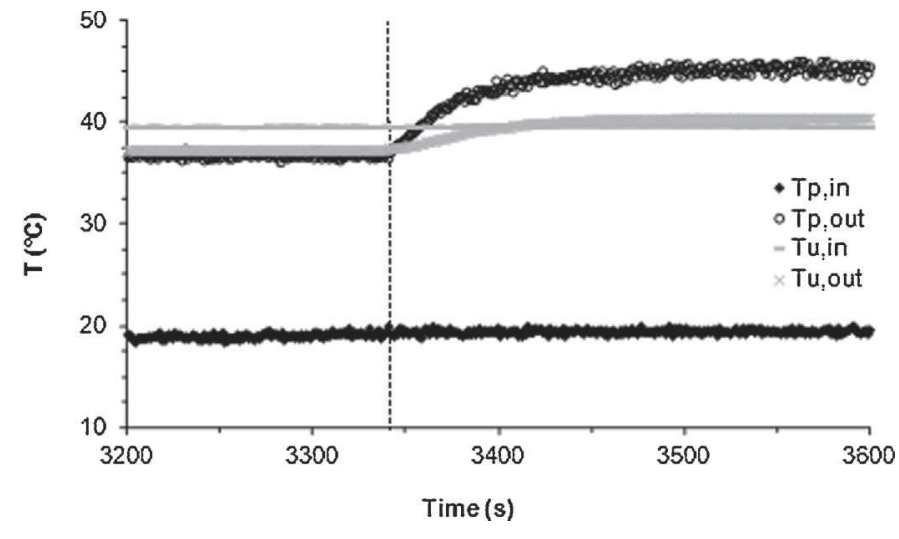

Fig. 16. Temperature profiles for experiment No. 1. 
Table 6

Conversion rates of oxidation reaction experiments.

\begin{tabular}{|c|c|c|c|c|c|c|c|c|c|c|}
\hline \multirow[t]{2}{*}{ No. exp } & \multicolumn{3}{|c|}{ Process side } & \multicolumn{3}{|l|}{ Utility side } & \multicolumn{2}{|c|}{ Heat exchanged } & \multicolumn{2}{|c|}{ Conversion rate } \\
\hline & $F_{p}\left(\mathrm{Lh}^{-1}\right)$ & $T_{p, i n}\left({ }^{\circ} \mathrm{C}\right)$ & $T_{p, \text { out }}\left({ }^{\circ} \mathrm{C}\right)$ & $M_{u}\left(\mathrm{~kg} \mathrm{~h}^{-1}\right)$ & $T_{u, i n}\left({ }^{\circ} \mathrm{C}\right)$ & $T_{u, \text { out }}\left({ }^{\circ} \mathrm{C}\right)$ & $Q_{\text {losses }}(\mathrm{W})$ & $Q_{p}(\mathrm{~W})$ & Reactor & Dewar \\
\hline 1 & 4.7 & 17.6 & 43.9 & 113.0 & 39.7 & 39.9 & 16 & 435 & 60 & 59 \\
\hline 2 & 1.7 & 19.3 & 41.4 & 113.5 & 39.7 & 40.4 & 9 & 126 & 82 & 94 \\
\hline 3 & 2.3 & 20.0 & 43.4 & 113.0 & 39.7 & 41.1 & 13 & 195 & 88 & 91 \\
\hline 4 & 2.3 & 20.7 & 51.0 & 112.0 & 49.6 & 50.7 & 16 & 253 & 93 & 100 \\
\hline 5 & 2.3 & 21.1 & 59.2 & 112.5 & 59.4 & 60.1 & 13 & 318 & 95 & 100 \\
\hline
\end{tabular}

Table 7

Arrhenius parameters reported in the literature for the reaction of sodium thiosulfate oxidation by hydrogen peroxide.

\begin{tabular}{|c|c|c|c|}
\hline Authors & $k_{0}\left(\mathrm{~L} \mathrm{~mol}^{-1} \mathrm{~s}^{-1}\right)$ & $E_{a} / R(\mathrm{~K})$ & $E_{a}\left(\mathrm{~J} \mathrm{~mol}^{-1}\right)$ \\
\hline Cohen and Spencer [29] & $\begin{array}{l}6 \\
.85 \times 10^{11}\end{array}$ & 9200 & 76,489 \\
\hline Lo and Cholette [30] & $\begin{array}{l}2 \\
.13 \times 10^{10}\end{array}$ & 8238 & 68,490 \\
\hline Lin and $\mathrm{Wu}[31]$ & $\begin{array}{l}2 \\
.00 \times 10^{10}\end{array}$ & 8238 & 68,490 \\
\hline Grau et al. [32] & $\begin{array}{l}8 \\
.13 \times 10^{11}\end{array}$ & 9156 & 76,123 \\
\hline
\end{tabular}

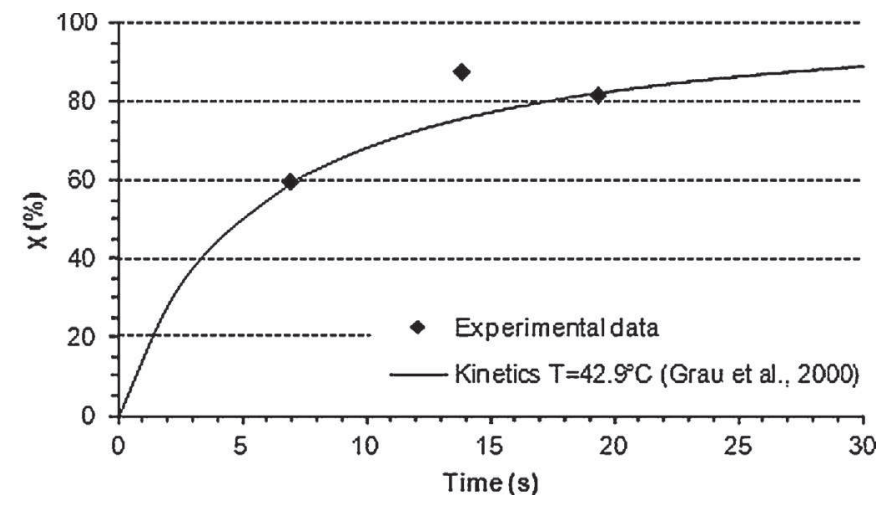

Fig. 17. Comparison of the theoretical conversion and the experimental ones at $T_{u, i n}=39.7^{\circ} \mathrm{C}$.

Fig. 18 highlights the influence of the utility stream temperature (between 50 and $60^{\circ} \mathrm{C}$ ) on the conversion profile for a fixed process flowrate of $2.3 \mathrm{Lh}^{-1}$ which corresponds to a residence time of $13.8 \mathrm{~s}$. As expected, the higher the temperature, the faster the reaction. But at these temperatures the reaction is almost completed at the reactor outlet, which certainly results in a most important error

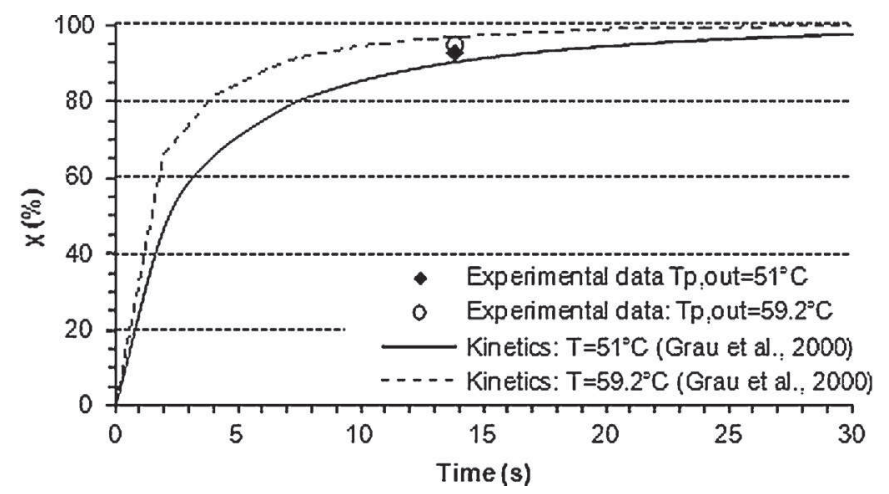

Fig. 18. Comparison of the theoretical conversion and the experimental ones at $F_{p, i n}=2.3 \mathrm{~L} \mathrm{~h}^{-1}$. in the experimental determination of the conversion. However the discrepancy between the conversions obtained from the Grau et al. kinetic data and the experimental values is lower than $4 \%$ in both cases.

The results obtained in this study show a good agreement with Grau et al. kinetic parameters which have been obtained from batch experiments whatever the flowrate $\left(R e_{p}=879-2481\right)$ and the temperature $\left(T_{u, i n}=39.7-59.4^{\circ} \mathrm{C}\right)$. As a consequence it confirms that the mixing time (cf. Fig. 8: $t_{m}<0.1 \mathrm{~s}$ for the flowrate range studied) is not a limiting parameter for such a fast reaction.

\subsubsection{Comparison with batch reactors}

The reaction has been performed at three utility stream temperatures around 40,50 and $60^{\circ} \mathrm{C}$. At room temperature the reaction could not start. Thus the utility stream has been heated so as to first initiate the reaction, then accelerate its kinetics and finally control the reactor temperature to avoid thermal runaway (the process fluid temperatures at the rector outlet were indeed equal to $43.4,51.0$ and $59.2^{\circ} \mathrm{C}$ ). It is now interesting to compare the heatexchanger reactor behaviour to the one of a classical batch reactor.

If we consider an operating temperature of $T \approx 60^{\circ} \mathrm{C}$ the heat exchanged in the heat-exchanger/reactor per unit of fluid volume equals:

$\frac{Q}{V}=12 \times 10^{3} \mathrm{~kW} \mathrm{~m}^{-3}$

Table 8 gives the geometrical parameters of various batch reactors whose volume ranges from $1 \mathrm{~L}$ to $1 \mathrm{~m}^{3}$. A is the heat exchange area of the double jacket. The heat exchanged per volume unit of the batch reactors $Q / V$ in the same reaction conditions as the heat exchanger ones are also detailed as well as the feeding times $\left(t_{c}\right)$ of

Table 8

Geometrical parameters of double jacket batch reactors, heat removal capacity and feeding times to safely perform the oxidation reaction.

\begin{tabular}{lllcc} 
Volume $\left(\mathrm{m}^{3}\right)$ & $1 \times 10^{-3}$ & $1 \times 10^{-2}$ & 0.1 & 1 \\
Diameter $(\mathrm{m})$ & 0.08 & 0.2 & 0.4 & 0.9 \\
Height $(\mathrm{m})$ & 0.2 & 0.3 & 0.8 & 1.4 \\
$A\left(\mathrm{~m}^{2}\right)$ & 0.055 & 0.22 & 1.13 & 4.6 \\
$Q_{\max } / V\left(\mathrm{~kW} \mathrm{~m}^{-3}\right)$ & 1200 & 500 & 250 & 100 \\
$t_{c}(\mathrm{~s})$ & 230 & 560 & 1120 & 2800 \\
\hline
\end{tabular}


a semi-batch reactor in which the oxidation reaction would have been performed. The calculation details are given in [20].

The maximal heat removed by the double jacket is at least 10 times less than the reaction heat generated in the heatexchanger/reactor. As a consequence this oxidation reaction could not be performed in a batch reactor without thermal runaway. A semi-batch mode is required and that is the reason why feeding times have been assessed in Table 8 . They range between 230 and $2800 \mathrm{~s}$. Feeding times and residence times are respectively characteristic of semi-batch and continuous modes. They cannot be directly compared. However the operation time in the continuous heat-exchanger/reactor was close to 30 s to achieve $100 \%$ conversion and it shows that by removing the heat transfer barrier, the reaction has been implemented under extreme operating conditions which allow to get closer to the kinetics characteristic times.

To complete the comparison, the next step, now, is to address the scale-up issue. The first point is to get laws concerning the evolution of the HEX reactor performances (heat and mass transfer, pressure drop, mixing, etc.) with the shape and the dimensions of the channel. First results have been proposed in [9] and experimental works are still in progress. This is a consequent work and CFD numerical simulations, once validated, will allow accelerating data acquisition process. Using these correlations it would then be possible to optimize the combination of both the channel characteristic size and the number of plates to satisfy scale-up demand according to different performances criteria like intensification factor, productivity, energy consumption, etc. Such an approach has been developed in the work of Fustier [32] in the case of a SiC HEX reactor and for an increase of the reactants flow rate by a factor 10.

\section{Conclusion}

Through this study the performances of a new continuous heat-exchanger/reactor were evaluated following an experimental approach. The aim was to reach good performances while maintaining low Reynolds number $(\operatorname{Re}<2000)$ for offering sufficient residence times to complete chemical conversion. It has been shown that the corrugated flow behaviour was close to a plug flow behaviour whatever the Reynolds number (between 300 and 2100). Darcy laws has been established between $R e=20$ and $R e=3000$. Below $R e=100$ the Darcy coefficient is close to the one in a straight tube which is interesting for low Reynolds applications (viscous fluids for instance).

Mixing times are quite low, especially for Reynolds number above $700\left(t_{m}<0.1 \mathrm{~s}\right)$. As a consequence, unless implementing an instantaneous or a very fast reaction, mixing should not be a limiting parameter in the heat exchanger/reactor.

Temperature profiles and heat transfer intensification factors highlight the good thermal performances of the heatexchanger/reactor $\left(5000-8000 \mathrm{~kW} \mathrm{~m}^{-3} \mathrm{~K}^{-1}\right)$. This allows the implementation of an exothermic reaction in safe conditions.

The test reaction of sodium thiosulfate oxidation by hydrogen peroxide has thus been carried out. This is a highly exothermic reaction $\left(\Delta H_{r}=-586.2 \mathrm{~kJ} \mathrm{~mol}^{-1}\right.$ of $\left.\mathrm{Na}_{2} \mathrm{~S}_{2} \mathrm{O}_{3}\right)$ which has been successfully implemented in the heat-exchanger/reactor under severe temperature conditions. The comparison with a batch reactor showed that thanks to the heat removal capacity of the heatexchanger/reactor, the reaction could be performed in operation times at least 10 times smaller than the operation times of a batch reactor.

These results highlight the heat removal ability of the heatexchanger/reactor for a liquid homogeneous phase reaction. It allows the implementation of exo- or endothermal reactions in extreme operating conditions. Theron et al. [8] also demonstrated the capacity of such process channel design to carry out a liquid-liquid reaction of microencapsulation by interfacial polycondensation. Even if such reaction is athermal it demonstrates the ability of such reactor to convey droplets with a $10 \%$ volume concentration with membrane under formation at their interface without any agglomeration phenomenon. Thus by combining its thermal performances and its hydrodynamic properties the heat exchanger/reactor exhibits interesting characteristics in the perspective of performing exothermic or endothermic two-phases reactions.

\section{References}

[1] A.I. Stankiewicz, J.A. Moulijn, Process intensification: transforming chemica engineering, Chem. Eng. Prog. 96 (2000) 22-34.

[2] B. Thonon, P. Tochon, Compact multifunctional heat exchangers: a pathway to process intensification, in: A. Stankiewicz, J.A. Moulijn (Eds.), Re-engineering the Chemical Processing Plant, Dekker, New-York, 2004.

[3] Z. Anxionnaz, M. Cabassud, C. Gourdon, P. Tochon, Heat exchanger/reactors (HEX reactors): concepts, technologies: state-of-the-art, Chem. Eng. Proc. 47 (2008) 2029-2050.

[4] S. Elgue, A. Conte, C. Gourdon, Y. Bastard, Direct fluorination of 1,3-dicarbonyl compound in a continuous flow reactor at industrial scale, Chim. Oggi/Chem. Today 30 (4) (2012) 18-21.

[5] E. Santacesaria, M. Di Serio, R. Tesser, L. Casale, D. Verde, R. Turco, A. Bertola, Use of a corrugated plates heat exchanger reactor for obtaining biodiesel with very high productivity, Energy Fuels 23 (2009) 5206-5212.

[6] C. Habchi, D. Della Valle, T. Lemenand, Z. Anxionnaz, P. Tochon, M. Cabassud, C. Gourdon, H. Peerhossaini, A new adaptative procedure for using chemical probes to characterize mixing, Chem. Eng. Sci. 66 (2011) 3540-3550.

[7] Z. Anxionnaz, F. Theron, P. Tochon, R. Couturier, P. Bucci, F. Vidotto, C. Gourdon, M. Cabassud, S. Lomel, G. Bergin, S. Bouti, H. Peerhossaini, T. Lemenand, C. Habchi, RAPIC project: toward competitive heat-exchanger/reactors, in: 3rd European Process Intensification Conference, Manchester, UK, June 20-23, 2011.

[8] F. Theron, Z. Anxionnaz, N. Le Sauze, M. Cabassud, Transposition from a batch to a continuous process for microencapsulation by interfacial polycondensation, Chem. Eng. Proc. 54 (2012) 42-54

[9] Z. Anxionnaz-Minvielle, M. Cabassud, C. Gourdon, P. Tochon, Influence of the meandering channel geometry on the thermo-hydraulic performances of an intensified heat exchanger/reactor, Chem. Eng. Proc. 73 (2013) $67-80$.

[10] P. Tochon, R. Couturier, Z. Anxionnaz, S. Lomel, H. Runser, F. Picard, A. Colin, C. Gourdon, M. Cabassud, H. Peerhossaini, D. Della Valle, T. Lemenand, Toward a competitive process intensification: a new generation of heat exchangerreactors, Oil Gas Sci. Technol. 65 (5) (2010) 785-792.

[11] R. Couturier, P. Tochon, F. Vidotto, Method for making a heat exchanger system, preferably of the exchanger/reactor type, French Patent, WO2010/034692 (2010)

[12] Y. Kato, Y. Tada, M. Ban, Y. Nagatsu, S. Iwata, K. Yanagimoto, Improvement of mixing efficiencies of conventional impeller with unsteady speed in an impeller revolution, J. Chem. Eng. Jpn. 38 (9) (2005) 688-691.

[13] A.W. Nienow, On impeller circulation and mixing effectiveness in the turbulent flow regime, Chem. Eng. Sci. 52 (15) (1997) 2557-2565.

[14] W.R. Dean, Fluid motion in a curved channel, Proc. Roy. Soc. Lond. Ser. A 121 (1928) 402-420.

[15] S. Sugiyama, T. Hayashi, K. Yamazaki, Flow characteristics in the curved rectangular channels, Bull. Jpn. Soc. Mech. Eng. 26 (216) (1983) 964-969.

[16] F. Jiang, K.S. Drese, S. Hardt, M. Küpper, F. Schönfeld, Helical flows and chaotic mixing in curved micro channels, AIChE J. 50 (9) (2004) 2297-2305.

[17] N.R. Rosaguti, D.F. Fletcher, B.S. Haynes, Laminar flow and heat transfer in a periodic serpentine channel, Chem. Eng. Technol. 28 (3) (2005) 353-361.

[18] H. Fellouah, C. Castelain, A. Ould El Moctar, H. Peerhossaini, A criterion for detection of the onset of Dean instability in Newtonian fluids, Eur. J. Mech. B: Fluids 25 (2006) 505-531.

[19] L. Despenes, S. Elgue, C. Gourdon, M. Cabassud, Impact of the material on the thermal behaviour of heat exchangers-reactors, Chem. Eng. Proc. 52 (2012) $102-111$.

[20] Z. Anxionnaz, M. Cabassud, C. Gourdon, P. Tochon, Transposition of an exothermic reaction from a batch to an intensified continuous one, Heat Trans. Eng. 31 (9) (2010) 788-797

[21] L. Prat, A. Devatine, P. Cognet, M. Cabassud, C. Gourdon, S. Elgue, F. Chopard, Performance evaluation of a novel concept "open plate reactor" applied to highly exothermic reactions, Chem. Eng. Technol. 28 (9) (2005) 1028-1034.

[22] M.D. Grau, J.M. Nougues, L. Puigjaner, Batch and semibatch reactor performance for an exothermic reaction, Chem. Eng. Proc. 39 (2000) 141-148.

[23] A.M. Benkouider, J.C. Buvat, J.M. Cosmao, A. Saboni, A Fault detection in semibatch reactor using the EKF and statistical method, J. Loss Prevent. Process Ind. 22 (2009) 153-161. 
[24] L. Vernieres-Hassimi, M.A. Abdelghani-Idrissi, D. Seguin, Experimental and theoretical steady state maximum temperature localization along an exothermic tubular reactor, Open Chem. Eng. J. 2 (2008) $57-65$.

[25] W. Benaissa, S. Elgue, N. Gabas, M. Cabassud, D. Carson, M. Demissy, Dynamic behaviour of a continuous heat exchanger/reactor after flow failure, Int. J. Chem. React. Eng. 6 (2008),

[26] D.R. Lide, Handbook of Chemistry and Physics, 87th ed., CRC Press, Boca Raton, FL, 2006

[27] J. Barthel, N.G. Schmahl, Thermometric redox titrations, Zeitung Anal. Chem. 207 (2) (1965) 81-90
[28] F. H. Funk, A.W. Herlinger Convenient preparation of standard thiosulfate solutions, Anal. Chem. 47 (4) (1975) 767.

[29] W.C. Cohen, J.L. Spencer, Determination of chemical kinetics by calorimetry, Chem. Eng. Prog. 58 (12) (1962) 40-41.

[30] S.N. Lo, A. Cholette, Experimental study on the optimum performance of an adiabatic MT reactor, Can. J. Chem. Eng. 50 (1972) 71-80.

[31] K.F. Lin, L.L. Wu, Performance of an adiabatic controlled cycled stirred tank reactor, Chem. Eng. Sci. 36 (1981) 435-444.

[32] C. Fustier, Développement d'un réacteur intensifié en Carbure de Silicium pour la transposition en continu de réactions d'hydrosilylation(Ph.D. Thesis), Institut National Polytechnique de Toulouse, Toulouse, 2012. 